\title{
WHY DID UKRAINIAN \\ RED ARMY MEN GO OVER TO THE GERMANS? THE CASE OF DEFECTORS TO THE WEHRMACHT'S 296 INFANTRY DIVISION, 1942-1943*
}

\begin{abstract}
The purpose of this study is to analyse the reasons for defection among Ukrainian Red Army men during World War II. The research methodology is a combination of quantitative and qualitative methods. We analyse interrogation reports of Red Army defectors created by the counter-intelligence officer of the German 296 ID both for the reasons defectors gave for crossing the frontline and for the frequency their reasons fell into certain categories. We compare these data with the larger group of Soviet defectors, including other Soviet nationalities. The scientific novelty consists in combining cultural history with quantification and extending a methodology developed for Red Army defectors as a whole to the subset of Ukrainians among them. The article's source base is multi-archival, drawing on Ukrainian and Russian archives in addition to the German military archive. Conclusions. In the aggregate Ukrainians were not motivated in significantly different ways from Soviet defectors of other nationalities. Ukrainians were more often politicized than other nationalities, but the broad social and political grievances they expressed were shared by many Soviet citizens. Many of the Ukrainian defectors who were politicized enough to want to fight against the Soviets to liberate their "homeland" were imagining this home as the multi-national Soviet Union rather than a Ukrainian national territory. The political grievances which motivated these politicized Ukrainians were political (lack of freedom, repression) or social (the collective farms, terrible living conditions) rather than national (freedom for Ukraine). Ukrainian nationalists were in the minority among defectors, and tended to come from the formerly Polish territories annexed after the start of World War II in Europe.
\end{abstract}

Ключові слова: World War II, defectors, Ukrainian defectors, Wehrmacht's 296 Infantry Division.

Ukraine was among the Soviet republics which suffered most in World War $\mathrm{II}^{1}$. Entirely occupied by Germany and its allies, a brutal regime of destruction, counter-insurgency, genocide, deportations to work in Germany, and

* An earlier version was presented at the Australian Historical Association Conference in Canberra, 3 July 2018. I would like to thank Oleg Beyda, David Stahel, and Yurii Shapoval for comments.

${ }^{1}$ For broad histories of Ukrainian suffering in the $20^{\text {th }}$ Century see: Snyder T. Bloodlands. Europe between Hitler and Stalin. - London, 2010; Liber G.O. Total Wars and the Making of Modern Ukraine, 1914-1954. - Toronto, 2016. 
extraction of resources bled the country white ${ }^{2}$. Population losses were staggering. The regions liberated by April 1944 held nearly 40\% fewer people than before the German invasion ${ }^{3}$. Cities were particularly badly hit, their populations standing on average at $37 \%$ of the 1941 number. Kyiv had only $36 \%$ of its pre-war population, Rivne $-34 \%$, Ternopil $-34 \%$, and Zaporizhzhia $-23 \%^{4}$. Such numbers of course included those drafted into the army by the Soviets and those evacuated east in 1941, but they accounted for a minority of the losses. In Kharkiv, for example, which lacked nearly half a million people by 1944, only some 65000 had been evacuated in September-October 19415. Overall, maybe 4 million people had been removed from Ukraine to the Soviet hinterland by the end of $1941^{6}$, about $10 \%$ of a pre-war population of 41,3 million $^{7}$. Many more died: 5,2 million civilians and nearly 1,6 million soldiers, or about $16 \%$ of the population of Ukraine ${ }^{8}$. Such numbers are abstract, dry representations of years of living under a regime of terror, mass killing, exploitation, hunger, and violence.

With brutalization came collaboration - a topic with renewed relevance in today's history wars between Russia and Ukraine ${ }^{9}$. Notwithstanding contemporary images proliferated in Russian media, Ukrainians were not particularly likely to collaborate with the Germans ${ }^{10}$. As far as military collaborators are concerned, they were in fact underrepresented both at the time ${ }^{11}$ and in postwar prosecutions of traitors and accomplices of the German occupation regime ${ }^{12}$.

${ }^{2}$ Berkhoff K.C. Harvest of Despair: Life and Death in Ukraine under Nazi Rule. - Cambridge; London, 2004; Україна: Політична історія. XX - початок XXI століття / Ред. В.Литвин. - К., 2007. - C.757-813; Pohl D. Die Herrschaft der Wehrmacht: Deutsche Militärbesatzung und einheimische Bevölkerung in der Sowjetunion 1941-1944. - Frankfurt a. M., 2011.

${ }^{3}$ Центральний державний архів громадських об'єднань України (hereafter - ЦДАГО України). - Ф.1. - Оп.23. - Спр.3976. - Арк.3. At the time $86 \%$ of Ukrainian territory had been liberated from German occupation.

4 Tам само. - Арк.5. On the re-population of Kyiv after liberation see: Blackwell M.J. Kyiv as a Regime City: The Return of Soviet Power after Nazi Occupation. - Rochester, 2016.

${ }_{5}^{5}$ ЦДАГО України. - Ф.1. - Оп.23. - Спр.24. - Арк.15. On 1944 population and losses: Там само. - Спр.3976. - Арк.5. According to German estimates, in the summer of 1941 between 10\% and $20 \%$ of the population managed to evacuate or flee. See: Pohl D. Die Herrschaft... - S.122.

${ }_{6}^{6}$ Куманев Г.А. Эвакуация населения из угрожаемых районов СССР в 1941-1942 гг. // Население России в XX веке: Исторические очерки: В 3 т. - Т.2: 1940-1959 / Отв. ред. Ю.А.Поляков. - Москва, 2001. - С.71.

7 Рогачевская Л.С., Кабузан М.В. Население и территория СССР и РСФСР накануне Великой Отечественной войны // Там же. - С.16.

8 Эрлихман B.В. Потери народонаселения в XX веке: Справочник. - Москва, 2004. - С.34.

9 On the Russian side of the history wars see: Edele M. Fighting Russia's History Wars: Vladimir Putin and the Codification of World War II // History and Memory. - 2017. - Vol.29. - No.2. P.90-124. On Ukraine, see for example: Плохий C. Как Сталин потерял голову: Вторая мировая война и войны памяти в современной Украине // СССР во Второй мировой войне: Оккупация, Холокост, сталинизм / Отв. ред. и сост. О.Будницкий, Л.Новикова. - Москва, 2014. - С.392-410.

10 See: Golczewski F. Ukrainische Reaktionen auf die deutsche Besetzung 1939/41 // Anpassung, Kollaboration, Widerstand: Kollektive Reaktionen auf die Okkupation / Ed. W.Benz et al. - Berlin, 1996. - S.199-211.

${ }^{11} 16 \%$ of Soviet citizens fighting with the Germans came from Ukraine. See: Edele M. "What Are We Fighting For?" Loyalty in the Soviet War Effort, 1941-1945 // International Labor and Working-Class History. - 2013. - Vol.84. - No. Fall. - P.259. Table 4. Before the war, more than $21 \%$ of the Soviet population had lived in Ukraine (as of 1 January 1940): Рогачевская Л.С., Кабузан М.В. Население и территория СССР и РСФСР накануне Великой Отечественной войны // Население России в XX веке. - С.16.

12 Overall, between 1943 and 1953, in the Soviet Union 257178 people were arrested for "treason and collaboration with the German occupiers" and another 151769 as "accomplices of 
Given the prominence of nationalist guerrillas in wartime Ukraine, however, it might be worth asking if the motivations to serve the Germans were different for Ukrainians than for Russians. Did Ukrainians side with the Germans to free Ukraine from Bolshevism? ${ }^{13}$

Historians of collaboration have pointed to the complex motivations underlying this phenomenon. Coercion, survival, and accommodation with the occupying forces played a central role. Ideological commitment might, too, but this aspect is hard to untangle from the others ${ }^{14}$. Something similar is true for the motivation of defection, by which I mean the voluntary crossing of the frontline from the Soviet to the German side. "Defector" is a rough English equivalent for what the Germans called Überläufer and the Soviets перебежчики - soldiers who voluntarily surrendered to the enemy. Their history overlaps with those of wartime captivity on the one hand and with the history of collaboration on the other. But these histories are also distinct: not every defector became a collaborator and the majority of POWs had not surrendered on their own ac$\operatorname{cord}^{15}$. In contrast to the work on collaborators, for defectors we have at least some evidence which was not produced in the context of post-war prosecutions ${ }^{16}$,

the German-Fascist occupiers (see: Edele M. Stalin's Defectors: How Red Army Soldiers Became Hitler's Collaborators, 1941-1945. - Oxford, 2017. - P.141, table 7.1). Together, these would be 408947 traitors, collaborators, and accomplices. In Ukraine, during the same time period, 80075 (or 19,5\% of the combined all-Union numbers) were arrested for treason and as accomplices. Нікольський B.M. Репресивна діяльність органів державної безпеки СРСР в Україні (кінець 1920-х - 1950-ті рр.): Історико-статистичне дослідження. - Донецьк, 2003. - С.207, 211. On the "cleansing" of formerly occupied Soviet territories see: Voisin V. L'URSS contre ses traîtres: L'Épuration soviétique (1941-1955). - Paris, 2015.

${ }_{13}$ This was, essentially, the tactic of the OUN, until the Germans made it clear that they were not interested in such collaboration. See: Rossolinski-Liebe G. Stepan Bandera: The Life and Afterlife of a Ukrainian Nationalist: Fascism, Genocide, and Cult. - Stuttgart, 2014.

${ }^{14}$ On Ukrainian collaborators see, for example: Potichnyj P.J. Ukrainians in World War II Military Formations: An Overview // Ukraine during World War II: History and its Aftermath: A Symposium / Ed. by Y.Boshyk. - Edmonton, 1986. - P.61-66; Golczewski F. Organe der deutschen Besatzungsmacht: die ukrainischen Schutzmannschaften // Die Bürokratie der Okkupation: Strukturen der Herrschaft und Verwaltung im besetzten Europa / Ed. by W.Benz et al. - Berlin, 1998. - S.173-196; Kudryashov S. Ordinary Collaborators: The Case of the Travniki Guards // Russia: War, Peace and Diplomacy: Essays in Honour of John Erickson / Ed. by L.Erickson, M.Erickson. - London, 2005. - P.226-239; Прусин A. Украинская полищия и холокост в генеральном округе Киев, 1941-1943: действия и мотивации // Голокост і сучасність: Студії в Україні і світі. - 2007. - №1. - C.31-59; Black P. Foot Soldiers of the Final Solution: The Trawniki Training Camp and Operation Reinhard // Holocaust and Genocide Studies. - 2011. - Vol.25. - No.1. - P.1-99; Benz A. Handlanger Der SS: Die Rolle der Trawniki-Männer im Holocaust. - Berlin, 2015. On civilians see: Скоробогатов A.B. Харків у часи німецької окупації (1941-1943). - X., 2004. - C.128-174; Lower W. Nazi Empire-Building and the Holocaust in Ukraine. Chapel Hill, 2005. - P.101-106; Rudakova D. Soviet Women Collaborators in Occupied Ukraine 19411945 // Australian Journal of Politics \& History. - 2016. - Vol.62. - No.4. - P.529-545.

${ }_{15}$ There is a huge literature on Soviet POWs in German hands. The classic is: Streit K. Keine Kameraden: Die Wehrmacht und die sowjetischen Kriegsgefangenen 1941-1945, new ed.: Bonn, 1997. For a bibliographic overview to the mid-1990s see: Osterloh J. Sowjetische Kriegsgefangene 1941-1945 im Spiegel nationaler und internatioanler Untersuchungen. Forschunsüberblick und Bibliographie, 2nd. rev. ed. - Dresden, 1996. Important recent contributions include: Шнеер А. Плен: Советские военнопленные в Германии, 1941-1945. - Москва; Иерусалим, 2005; Hilger A., Overmans R., Polian P. Rotarmisten in deutscher Hand: Dokumente zu Gefangenschaft, Repatriierung und Rehabilitierung sowjetischer Soldaten des Zweiten Weltkrieges. - Paderborn, 2012.

${ }_{16}$ On the use and problems of war-crime trial cases see: Penter T. Collaboration on Trial: New Source Material on Soviet Postwar Trials against Collaborators // Slavic Review. - 2005. - Vol.64. No.4. - P.782-790; Dumitru D. An Analysis of Soviet Postwar Investigation and Trial Documents and 
but shortly after the deeds in question: interrogation protocols by German counterintelligence.

Can be believe the notes of German officers who interrogated desperate men who had just so survived usually hair-raising ordeals to get across the frontline? The pragmatic answer is that our choice is between having no information at all and carefully using them. Of course, there is no need to be naive about these sources, which included a variety of distortions. The intentions of the interrogators were not among them. The Germans wanted to find out what motivated Soviets to stop fighting. This was essential information to fuel the propaganda across the frontline ${ }^{17}$. Hence, there was a fairly strong incentive to get this information right. That still leaves the problem of German preconceptions and the potential for mis-categorization or mis-translation ${ }^{18}$. We will deal with some of them below.

But there is also the question if the Soviet defectors told the truth. Would they not tell the Germans what these wanted to hear? ${ }^{19}$ If the archival record would be full of statements about "hatred against the Jews" ${ }^{20}$, about defectors not wanting to "fight for the Jews" ${ }^{21}$ or "the Jews and the commissars"22 this conclusion would be warranted. However, such statements were remarkably rare. Defectors often did not understand their situation, their real options, or what the Germans wanted. At its most disturbing, such mis-apprehensions led some Jews to defect to their certain execution - and not hide the fact that they were Jewish ${ }^{23}$. The German officers also frequently complained that the defectors were more interested in talking about their terrible lives and what had led them to decide to cross the frontline than passing on valuable information about tactical issues ${ }^{24}$. Clearly, the defectors had agency not only in what they did - crossing the frontline - but also in what they said about it.

My previous work ${ }^{25}$ on Soviet defectors in World War II has shown that:

1. Soviet soldiers were more likely to defect that other Allied military personnel.

2. Their motivations to do so were complex, ranging from simple survivalism to ideologically motivated resistance to Stalinist rule.

3. Ukrainians were slightly over-represented among Soviet defectors ${ }^{26}$.

Their Relevance for Holocaust Studies // The Holocaust in the East: Local Perpetrators and Soviet Responses / Ed. by M.David-Fox, P.Holquist, and A.M.Martin. - Pittsburgh, 2014. - P.142-157.

17 Buchbender O. Das tönende Erz: Deutsche Propaganda gegen die Rote Armee im Zweiten Weltkrieg. - Stuttgart, 1978. See also: Idem. Heil Beil! Flugblattpropaganda im Zweiten Weltkrieg: Dokumentation und Analyse. - Stuttgart, 1974; Buchbender O., Schuh H. Die Waffe, die auf die Seele zielt: Psychologische Kriegsführung 1939-1945. - Stuttgart, 1983.

18 Förster J. Zum Rußlandbild der Militärs 1941-1945 // Das Rußlandbild Im Dritten Reich / Ed. by H.-E.Volkmann. - Cologne; Weimar; Vienna, 1994. - S.140-163.

19 The more intelligent among German soldiers were well aware of this danger. See: Kuby E.

Mein Krieg: Aufzeichnungen aus 2129 Tagen, $3^{\text {rd }}$ ed. - Berlin, 2010. - P.237.

${ }^{20}$ German Military Archive, Freiburg (henceforth - BA-MA): BA-MA. - RH 26-296/107. Überläufer Fragebogen, 2.7.43.

${ }^{21}$ Ibid. - RH 26-296/102.

${ }^{22}$ Ibid. - FC-35 16-P. 25. Inf. Division (mot.), Abt. Ic, Vernehmung von 2 Überläufer des II.

Batls. S.R.1285, Überläufer am 31.8.42 früh bei Gorodischtsche (September 1942).

${ }^{23}$ Edele M. Stalin's Defectors... - P.93-94.

${ }^{24}$ BA-MA. - RH 24-26/125, folio 13-15, here: 13-14. "Erfahrungen bei Gefangenenvernehmungen" (1941).

${ }^{25}$ Edele M. Stalin's Defectors.

26 The prominence of Ukrainians among defectors is supported by a variety of sources. The database on defectors 296 ID used below is only one of these sources (see: Edele M. Stalin's Defectors... - P.86-87). German officers of other units also thought that they were among the 
Building on this prior work, this essay sets out to investigate what motivated Ukrainian as opposed to Soviet defectors to cross the frontline? Were Ukrainian defectors in any way different from Soviet defectors overall? In particular, what role id Ukrainian nationalism play in decisions to risk life and limb and cross over to the enemy?

To answer these questions I use a database developed for my 2017 book Stalin's Defectors. Why Red Army Soldier became Hitler's Collaborators, but not yet exploited to pursue this problematic. It includes information on all defectors registered by the 296 German Infantry Division (296 ID) between April 1942 and December $1943^{27}$. At the time, the 269 ID was part of Army Group Center, fighting first with the $2^{\text {nd }}$ Panzer Army at Orel in Russia, then, from September 1943, with the $9^{\text {th }}$ Army at Gomel and Babruysk in Belarus ${ }^{28}$. Altogether, the database holds information on 334 defectors, 46 of them (or 14\%) self-identified as Ukrainian. If we eliminate those soldiers from the sample whose nationality was not noted, the share of Ukrainians increases to $19 \%{ }^{29}$. Below I analyse this dataset both quantitatively and qualitatively, supplemented by other, more fragmentary, and therefore un-quantifiable archival sources where appropriate. This addition of further cases from other sources increases the sample for the qualitative conclusion from 46 to 49 .

This number, of course, is still but a drop in the ocean: overall, there were at least 117000 Red Army defectors in 1942-1945 alone, a significant share of them Ukrainians ${ }^{30}$. Whether or not our examples are representative is unclear at this stage of research. Although historians often draw far-reaching conclusions from small samples, sometimes even from one single case ${ }^{31}$, the results presented here should be seen as preliminary. A much fuller study of interrogation reports remains to be conducted to test, confirm, or falsify these conclusions. Such an investigation would require a data-set coherent enough for both qualitative and quantitative analysis. Historians face immense methodological problems in this respect. On the one hand, the records on division level are fragmentary, both because counter-intelligence officers differed widely in how detailed notes they took, and because records were lost or destroyed during retreats. Focusing on

most likely groups to defect. See, for example: BA-MA. - RH 24-17/155, folio 92, 93, 103, 127, 131, 134, 141, 205; RH 24-17/170, folio 101 (reports from summer 1941); RH 24-26/132 (summary of experience August 1941 - May 1942); RH 24-26/278, Anlage 5a, folio 4. „Das XXVI. Armeekorps im Rußlandfeldzug am linken Flügel der Heeresgruppe Nord vom 20. August 1941 bis 6. Mai 1942”. The Soviet command also thought so, ordering in August 1941 to pull all soldiers out of the frontline who hailed from the occupied territories. See: Ibid. - RH 24-17/156, folio 63. The heavy losses eventually forced the Red Army to send them back to the fighting units already by March 1942. See: Ibid. - RH 24-17/185, folio 153, 156.

${ }_{27}$ The raw data is contained in three files; BA-MA. - RH 26-296/97 (1942), RH 26-296/102 (1943), RH 26-296/107 (1943). There is also a file with more fragmentary earlier reports, which were not included: RH 26-296/93.

${ }_{28}$ Tessin G. Verbände und Truppen der deutschen Wehrmacht und Waffen-SS im Zweiten Weltkrieg 1939-1945. - Vol.9. - Osnabrück, 1974. - S.296.

${ }^{29}$ Edele M. Stalin's Defectors. - P.86, table 5.4.

${ }^{30}$ Ibid. - P.21, 31. There are no overall data for the year with likely the highest tally: 1941.

${ }^{31}$ For example: Hellbeck J. Fashioning the Stalinist Soul: The Diary of Stepan Podlubnyi (19311939). // Jahrbücher für Geschichte Osteuropas. - 1996. - Vol.44. - No.3. - P.344-375. 
higher military levels (corps, armies, or army groups) introduces a severe selection bias, because only defectors likely to have interesting information or those with potential for collaboration were forwarded for further interrogation from the divisions ${ }^{32}$.

Overall, my source-base shows little evidence that in the aggregate Ukrainians were motivated in significantly different ways from other defectors. The data-set of the 296 ID shows a higher degree of politicization of Ukrainians, but the broad social and political grievances they expressed were shared by many Soviet citizens. As far as a national aspect is concerned, the evidence suggests that many of the Ukrainian defectors who were politicized enough to want to fight against the Soviets to liberate their "homeland" were imagining this home as the multi-national Soviet Union rather than a Ukrainian national territory. Most of the Ukrainian defectors had grown up in the Soviet Union. Many had at some point lived outside of the Ukrainian SSR. Hence, they quite naturally imagined the political space they wanted to liberate as the territory of the Soviet Union. The political grievances which motivated most of these politicized Ukrainians were political (lack of freedom, repression) or social (the collective farms, terrible living conditions) rather than national (freedom for Ukraine). Ukrainian nationalists were in the minority among defectors, and tended to come from the formerly Polish territories annexed after the start of World War II in Europe.

\section{Motivation}

We begin our investigation by comparing the relative weight of eight broad reasons to go over to the enemy (table 1). These categories are the result of grouping together the spontaneous and diverse answers defectors gave to the open ended question about why they had decided to go over to the Germans ${ }^{33}$. The first four are relatively abstract reasons. "Survivalism" denotes the will to escape death at any cost without citing any moral or political reason. It was a largely negative sentiment, an absence of loyalty or devotion to any of the warring sides. As one Ukrainian deserter, escapee from German captivity, and defector put it in 1945: "What are we fighting for? It would be better if Hitler and [...] Stalin would come out and fight [among themselves]. He who wins", he continued, "his government also should also get victory". The people, meanwhile, should be left alone ${ }^{34}$. "Defeatism" was slightly different from pure survivalism. It relied on an analysis, however rudimentary and however misguided, of the military situation as hopeless. Defeatists might well have continued to put their life on the line if their side was holding firm or advancing. But they did not see the point of dying for what they perceived as a lost cause. Defeatism could shade over into political reasoning. In my original research I made a distinction between "political disaffection" and "active anti-Stalinism". The former referred to disgust at the Stalinist political system, its lack of democracy, collective farms,

${ }^{32}$ See the discussion: Edele M. Stalin's Defectors... - P.81-84, 89-90, 97-100.

${ }^{33}$ For an elaboration of these categories see: Ibid. - Chapter 6.

34 Государственный архив Российской Федерации. - Ф.А461. - Оп.1. - Д.1820. - Л.2, 11. 
repression, horrible living conditions, and thought control. Active anti-Stalinism was an extreme version of such opposition, which coupled disaffection with an at least rudimentary analysis of who was to blame and what was to be done. Typically, active anti-Stalinists expressed a desire to fight on the side of the Germans against Stalin's regime. This was an extreme position exactly because for most the point of defection was to escape the war, not to continue it on the other side.

Only a minority of defectors were "active anti-Stalinists" in this restrictive definition. Among the Ukrainians in our data-set from the 296 ID, there was not a single one thus classified. Much more widespread were four concrete reasons: the influence of German leaflet propaganda encouraging surrender; the often horrific living conditions in the Red Army; memory, either directly or via friends and family members, of allegedly fair treatment in German captivity during World War I; and the desire to return to one's family living on occupied territory.

Table 1

Reasons for Defection to 296 ID

\begin{tabular}{|l|c|c|}
\hline \multicolumn{1}{|c|}{ Reason } & $\begin{array}{c}\text { All Defectors } \\
(\mathbf{\%} ; \mathbf{N = 3 3 4 )}\end{array}$ & $\begin{array}{c}\text { Ukrainians } \\
(\mathbf{\%} ; \mathbf{N = 4 6 )}\end{array}$ \\
\hline Survivalism & 8,7 & 6,5 \\
\hline Defeatism & 33,5 & 37,0 \\
\hline Political disaffection & 34,4 & 41,3 \\
\hline Active anti-Stalinism & 1,2 & 0,0 \\
\hline German propaganda & 19,5 & 17,4 \\
\hline Living conditions in Red Army & 17,1 & 10,9 \\
\hline Desire to return to family & 12,3 & 30,4 \\
\hline Memory of WWI treatment & 3,0 & 0,0 \\
\hline
\end{tabular}

Note: Multiple answers were often given. Hence the shares do not add up to 100.

Two main numerical differences between Ukrainians and defectors overall stand out in table 1. First, nearly a third of the Ukrainians defected because they wanted to go home. This result makes perfect sense, of course, given the geography of occupation: "I simply want to go home", was not a reason people from unoccupied territories could give. While the Ukrainian defectors were a much more urban group than defectors to the 296 ID as a whole, the group that gave this reason was overwhelmingly rural. Of the 14 Ukrainian defectors who attempted to go back home, six were collective farmers and three others classified as "agricultural workers". Another was an agronomist, who would be classified under "professional" in table 1, but most likely lived and worked in a village. The rest 
were skilled workers, who might or might not live in a city: two locksmiths and a joiner. There was also one student, who wanted to go see his parents.

The second outstanding difference is that political disaffection was much more prevalent among Ukrainians, while living conditions in the Red Army, German leaflet propaganda, or the memory of captivity in World War I played a lesser role (the latter probably as function of the relative youth of the sample, see below). 19 of the 46 Ukrainian defectors in our sample cited political disaffection as a reason. This more widespread politicization is particularly striking given the age of the Ukrainian defectors. As table 2 shows, the Ukrainians who went over to the 296 ID were significantly younger than their peers. Nearly half of them were born since the revolution. Unless they hailed from the newly occupied territories, they had thus not known a political system other than Bolshevism ${ }^{35}$.

Table 2

Distribution of defectors to 296 ID by generation

\begin{tabular}{|l|c|c|}
\hline Birth Year & All Defectors (\%; N=334) & Ukrainians (\%; N=46) \\
\hline $1893-1899$ & 14,7 & 8,7 \\
\hline $1900-1916$ & 58,1 & 41,3 \\
\hline $1917-1925$ & 27,2 & 50,0 \\
\hline & $\mathbf{1 0 0 , 0}$ & $\mathbf{1 0 0 , 0}$ \\
\hline
\end{tabular}

Historians usually assume that the younger generation was more likely to be loyal to the regime and more willing to fight ${ }^{36}$. My own study of the defectors to the 296 ID found that defectors born since 1917 were least likely to be political, but also quite likely to be defeatist ${ }^{37}$. The latter finding is also borne out by the Ukrainian sub-sample examined here, which shows a significantly higher share of defeatist motivation (table 1). In table 4 we can also see that the politically motivated Ukrainians tended to be older, which is also consistent with my findings about the complete sample of defectors to the 296 ID.

The higher instance of overall politicization among the Ukrainian sub-sample is in part a function of the specifically Ukrainian experiences - famine,

35 Only three among the 46 Ukrainian defectors in my database hailed from the formerly Polish territories. They were all born in 1919: \#64 (a worker); \#120 (a collective farmer); and \#231 (an agriculturalist who owned 15 acres of land). See: BA-MA. - RH 26-296/97; RH 26-296/102.

${ }^{36}$ Сенявская E.C. 1941-1945: Фронтовое поколение: Историко-психологическое исследование. - Москва, 1995; Reese R. Why Stalin's Soldiers Fought: The Red Army's Military Effectiveness in World War II. - Lawrence, 2011. The overwhelmingly young women who served in the armed forced during the war have received particular attention recently. See: Krylova A. Soviet Women in Combat: A History of Violence on the Eastern Front. - Cambridge; New York, 2010; Markwick R.D., Cardona E. Soviet Women on the Frontline in the Second World War. Houndmills, 2012. For a recent study stressing ideological motivation see: Hellbeck J. Stalingrad: The City That Defeated the Third Reich. - New York, 2015.

${ }^{37}$ Edele M. Stalin's Defectors... - P.113-114. 
nationality policy, nearly constant terror since Stalin's revolution from above - and in part a function of social background. My overall investigation has concluded that Ukrainian defectors were slightly more politicized than other national groups (with the exception of Kazakhs, who had suffered even more from Stalin's revolution from above). But it has also shown that defectors from socially more privileged groups of Soviet society were more likely to defect for political reasons than, for example, "Stalin's peasants"38. And the Ukrainian sub-set is also skewed towards urban and professional groups, as table 3 shows.

\section{Table 3}

Class Composition of defectors to 296 ID

\begin{tabular}{|l|c|c|}
\hline \multicolumn{1}{|c|}{ Class } & $\begin{array}{c}\text { All Defectors } \\
(\mathbf{\%} ; \mathbf{N = 3 3 4 )}\end{array}$ & $\begin{array}{c}\text { Ukrainians } \\
(\mathbf{\%} ; \mathbf{N}=\mathbf{4 6})\end{array}$ \\
\hline Collective farmer & 38,3 & 23,9 \\
\hline Skilled worker or artisan & 35,9 & 37,0 \\
\hline Professional & 9,6 & 15,2 \\
\hline Industrial worker & 8,4 & 11,0 \\
\hline Agricultural worker & 3,6 & 6,5 \\
\hline Unknown & 3,6 & 2,2 \\
\hline Career soldiers & 0,6 & 4,3 \\
\hline Sum & $\mathbf{1 0 0 , 0}$ & $\mathbf{1 0 0 , 1}$ \\
\hline
\end{tabular}

Note: Analysing the class structure of defectors comes with some methodological problems ${ }^{39}$. The German interrogators asked for the defectors' profession, and what they wrote down was inevitably a mix between what their captives told them and what they recognized as a category. The sources don't usually tell us if a skilled worker works in industry, is an independent craftsman in the city, or has a skilled profession in a collective farm (hence the category "skilled worker or artisan" above). Likewise, it is unclear what exactly the Germans categorized as an "agricultural worker". These complications, however, are more important if we try to match up the German categories with Soviet class categories, as I have tried in my previous work. For our problematic here, the mis-match between the German and the Soviet categories does not matter as much: table 3 compares like with like.

If we drill deeper into the data-set, we find that among those Ukrainians with political motivations the over-representation of professionals was even stronger, making up nearly a quarter (21\%) of the sub-set; meanwhile, collective farmers were even less prominent among the Ukrainians than among defectors overall (table 4). Hence we can conclude that it was a combination of class and nationality in this particular sample which counter-acted the influence of generation: the politicized defectors were Ukrainian, urban, and professional.

${ }^{38}$ Edele M. Stalin's Defectors... - P.113-114; Fitzpatrick Sh. Stalin's Peasants: Resistance and Survival in the Russian Village after Collectivization. - New York; Oxford, 1994.

39 See: Edele M. Stalin's Defectors... - P.87-89. 
Table 4

Politically disaffected defectors to 296 ID

\begin{tabular}{|l|c|c|}
\hline & $\begin{array}{c}\text { All Nationalities } \\
(\mathbf{\%} ; \mathbf{N}=\mathbf{1 1 5})\end{array}$ & $\begin{array}{c}\text { Ukrainians } \\
(\mathbf{\%} ; \mathbf{N}=\mathbf{1 9})\end{array}$ \\
\hline $1893-1899$ & 18,3 & 21,1 \\
\hline $1900-1916$ & 59,1 & 42,1 \\
\hline $1917-1925$ & 22,6 & 36,8 \\
\hline Collective farmer & 36,5 & 21,1 \\
\hline Skilled worker or artisan & 30,4 & 36,8 \\
\hline Professional & 14,8 & 21,2 \\
\hline Industrial worker & 11,3 & 5,3 \\
\hline Agricultural worker & 3,5 & 5,3 \\
\hline Unknown/other & - & 10,5 \\
\hline
\end{tabular}

\section{The role of nationalism}

What, then, were the politics which motivated these urbanized Ukrainians to join the German side? Mostly, their concerns were not particularly "Ukrainian". Instead, they cited similar reasons non-Ukrainian defectors would: Some noted that they were "hostile" toward the Soviet system ${ }^{40}$. "Dissatisfaction with the Soviet System" could be cited on its own ${ }^{41}$, together with the hope to return home ${ }^{42}$, or in combination with a lacking desire to fight or the impact of leaflet propaganda ${ }^{43}$. "No desire to fight for the Soviet regime", was another laconic answer ${ }^{44}$. Others cited "general dissatisfaction with Soviet rule" ${ }^{45}$, or threat of persecution for defeatism: "Because of a statement that the German planes are better than the Russian ones, the defector was supposedly sentenced to death, a sentence commuted to frontline service. He had long planned to come across, but thus far did not find a possibility" ${ }^{46}$. Another Ukrainian had stated in the fall of 1941 that the Germans would soon have marched all the way to the Caspian, an utterance which had earned him a ten-year prison sentence he now tried to escape by crossing the frontline ${ }^{47}$. One particularly interesting case was a former priest (Pope), who was an enemy of Bolshevism for

${ }^{40}$ BA-MA. - RH 26-296/107.

${ }^{41}$ Ibid. - RH 26-296/97.

42 Ibid.

${ }^{43}$ Ibid.

44 Ibid.

${ }^{45}$ Ibid. - RH 26-296/102.

${ }^{46}$ Ibid. - RH 26-296/97. \#120 of my database, one of the three who hailed from the formerly Polish territories.

${ }^{47}$ Ibid. - RH 26-296/97. 
religious reasons and had served a 15 year camp sentence before getting to the frontline ${ }^{48}$.

Few, by contrast, displayed a sense of Ukrainian national consciousness. "As an Ukrainian, he hates the Soviet government", reads the note on one collective farmer, born in 1900, who also had family in occupied territory, where he wanted to sit out the war ${ }^{49}$. If we widen our source base beyond the defectors to the 296 ID, we can cite more such statements, including those which should be categorized as "active anti-Stalinist" in above definition. Outright nationalists intent at joining forces with the Germans to fight the Soviets tended to come from the newly incorporated regions in the west, which had been part of Poland in the interwar years ${ }^{50}$. An example is a man from Lvov (Lviv, Lwów, Lemberg), who claimed to be a member of "the national Ukrainian party" (that is, presumably, the OUN). He hoped he could "cooperate with the Germans in the development of Ukraine, either in the Ukrainian militia or in another role" ${ }^{51}$.

Not every mention of Ukraine had clearly nationalist overtones, however. It could be simply a geographic category. One defector noted that Ukrainians who hailed, like himself, from the occupied territories were pulled out of the frontline to prevent defections. This prompted him to cross the line before it was too late. His family was in Ukraine and he had been convicted for anti-Soviet agitation and thus needed to get away ${ }^{52}$.

In other cases, politically motivated defectors cited the liberation of their homeland as a reason to defect, but this "homeland" was not necessarily Ukraine. The word the German interrogator used in his reports was Heimat, a direct equivalent of Rodina in Russian or Bat'kivshchyna in Ukrainian. In all three languages, this term can refer to one's immediate region or city of origin or residence, once nation (Ukraine), or the larger state of which it was a part (the Soviet Union). This ambiguity was exploited by Soviet wartime propaganda attempting to motivate Soviet soldiers to fight by asking them to defend Rodina: home, hearth, women and children, but also the nation and the state ${ }^{53}$. When answering the question what had made them defect, Ukrainians displayed a similar ambiguity about the term.

"The defector does not agree with the Soviet regime. He understands the struggle of the German Wehrmacht as a fight for the liberation of his homeland from Bolshevism. One of his friends, who had fought in the Fall of 1941 in Ukraine, told him that masses of Russian soldiers were taken prisoner by

48 Ibid. - RH 26-296/102.

${ }^{49}$ Ibid. - RH 26-296/107.

${ }^{50}$ Шнеер А. Плен. - С.133-134.

51 BA-MA. - RH 24-17/299, folio 43. GFP b. XVIi A.K., Vernehmungsbericht, 11.2.42.

${ }_{52}$ Ibid. - RH 26-296/97.

${ }_{53}$ Edele M. Paper Soldiers: The World of the Soldier Hero According to Soviet Wartime Posters // Jahrbücher für Geschichte Osteuropas. - 1999. - Vol.47. - No.1. - P.89-108; Kirschenbaum L.A. "Our City, Our Hearths, Our Families": Local Loyalties and Private Life in Soviet World War II Propaganda // Slavic Review. - 2000. - Vol.59. - No.4. - P.825-847. More broadly see also: Berkhoff K.C. Motherland in Danger: Soviet Propaganda During World War II. - Cambridge, Mass., 2012. 
the Germans [...] The troops currently deployed at the front are so poorly trained, that a Russian victory is hopeless" ${ }^{54}$.

Other Ukrainians declared that they saw "in the German struggle the liberation of the Russian people", and hence defected "to no longer have to fight against his liberators" ${ }^{55}$. Others noted that they had already been under German occupation earlier in the war and thus knew the occupiers well. The Germans were "liberators of the Russian people" 56 .

At times, the German used the term Vaterland (fatherland, russ: Otechestvo; ukr.: Bat'kivshchyna), which would refer to a national or imperial entity and could not denote the local homeland. But this expression still left it ambivalent if the defector talked about the Russian/Soviet empire or Ukraine as a smaller nation state. "Both do not agree with the Soviet regime", reads one note. "They do not know why they should fight, because since the Revolution, they have not known any freedom in their fatherland" ${ }^{57}$.

Is this confusion between "Russia" and "Ukraine", the Soviet Union and the fatherland maybe a German rather than an Ukrainian bewilderment? Is what we hear the interrogator's rather than the defectors' thoughts? It is possible that the German officer did not make a difference between "Russia" and "Ukraine", although that's not very likely. For one, he did note the nationality of the defectors, and "Russian" was clearly delineated from "Ukrainian", as in the Soviet nationality categorization. Moreover, in World War I, Germany had occupied Ukraine and sponsored a Ukrainian national state as a buffer against Bolshevik Russia ${ }^{58}$. This history was well-known among soldiers who fought in the east ${ }^{59}$. It is unlikely that the officer would not have understood the difference between liberating "Russia" and liberating "Ukraine". It is, thus, at least possible, that what we encounter in these sources is a Russian imperial (Rossiiskii) consciousness, a hope to liberate not just Ukraine from Bolshevik oppression, but all the lands of the former Russian and now Soviet empire ${ }^{60}$.

This reading would conform to what other historians have found about Ukrainian national consciousness during the war and the occupation. In the minds of most ordinary Ukrainians, "our people" (nashi, svoi) included both Ukrainians and Russians at the time. The Great Famine of 1932-1933 was remembered vividly by most, but seen as a Bolshevik crime, not a Russian one.

${ }^{54}$ BA-MA. - RH 26-296/97.

55 Ibid.

${ }^{56}$ Ibid. - RH 26-296/107.

${ }^{57}$ Ibid. - RH 26-296/97.

${ }^{58}$ Von Hagen $M$. War in a European Borderland: Occupations and Occupation Plans in Galicia and Ukraine, 1914-1918. - Seattle; London, 2007.

${ }_{59}$ Pohl D. Die Herrschaft. - Part I (Chapters 1-4).

60 We find this consciousness both among military collaborators with the Germans, and among Russian and Ukrainian intellectuals supporting Stalin's expansionist foreign policy from 1939. See: Andreyev C. Vlasov and the Russian Liberation Movement: Soviet Reality and Émigré Theories. Cambridge, England, 1987; Plokhy S. The Call of Blood: Government Propaganda and Public Response to the Soviet Entry into World War II // Cahiers du Monde russe. - 2011. - Vol.52. No.2/3. - P.314-317. 
The short-lived post-revolutionary independent state was remembered, but without particular fondness or loyalty. The golden past was not Ukrainian, but Tsarist, that is, imperial ${ }^{61}$. As one Ukrainian Nationalist, a member of the Bandera fraction of the OUN, lamented:

"To a part of our compatriots, Moscow and the Muscovite region bit by bit have become the "motherland" and the Russian people and Russia - a common fatherland and a common society, that was at first Russian, then Orthodox, Slavic, proletarian, and now Soviet”62.

The lack of a national anchoring of anti-Bolshevik positions was also noted by the Germans. One officer noted after nearly three months' experience of interrogating Soviet POWs:

"Although the proportion of 'foreign peoples' (Fremdvölker) (Caucasians, Mongolians, Tartars, and also Ukrainians) was fairly high in the first few months, attempts to achieve national autonomy were only made if those interrogated realized that there would be preferential treatment [for such desires]. Meanwhile, the overwhelming majority was hostile towards the Bolshevik system, or at least coolly opposed to it"63.

Insofar as one can discern from the muted voices we hear through the filter of the interrogation reports, it was a kind of an imperial, anti-Bolshevik, but still revolutionary consciousness which animated many of the more politicized of the Ukrainian defectors to the 296 ID. It was not Russian rule, but the generalized bad life, the suffering and deprivation, and the ubiquitous repression, experienced more often than not either in person or as part of a family, which was cited as the reason for wanting to fight Bolshevism, or at least to stand back and let others fight it. The liberation in question was not a national one freedom for Ukraine - but the liberation of a "homeland" which was all-Soviet. One Ukrainian defector described his motivation thus:

"Reason for the defection: From his youth onwards his life in the Soviet Union was hard. As an apprentice he never got enough to eat, as assistant he earned so little that he could barely afford to buy clothes. Because he had failed to register with the police in Kyiv, he was jailed. As a result of a failed attempt at escape [from jail] he was sentenced to five years [...] and sent to forced labor in Murmansk. He again tried to flee, but was caught and heavily wounded in the process. He has thought for a long time about ways and means to escape the Soviet misery. [...] He wishes to fight with weapon in hand for the liberation of his homeland from the Bolshevik terror" ${ }^{64}$.

${ }^{61}$ Berkhoff K.C. Harvest of Despair. - Chapter 9.

${ }^{62}$ Ibid. - P.208.

${ }^{63}$ BA-MA. - RH 24-26/125, folio 13-15, here: 14 „Erfahrungen bei Gefangenenvernehmungen“ (1941).

${ }^{64}$ Ibid. - RH 24-17/210, folio 38rev. 294. ID, Abt. Ic, Vernehmungbericht Nr.87, 10 May 1943. 
This man had been born in 1918 in the Kyiv region but before the war had lived in Erevan (Armenia) - not an untypical case in the highly mobile society before the war ${ }^{65}$. What was his homeland? Most likely, it was the entire Soviet Union - the country he had grown up in, the space which had defined his pre-war life - from Kyiv to Murmansk and on to Erevan. His failure to mention Ukraine is typical: many of those who wanted to take up arms against the Bolsheviks had a deeply Soviet consciousness when it came to imagining the place it was worth fighting and dying for.

There can be no doubt that Ukrainian nationalism was a major force in wartime Ukraine. The OUN waged a determined and brutal, multi-sided struggle, which dragged on well into the post-war years. And yet, several historians have noted that ideologically committed nationalists were a radical minority, even if they were effective, organized, and armed. The majority of the Ukrainian population stood between the hammer of the nationalists and the anvil of the German and Soviet states, the latter represented first by the local partisans, later by NKVD and Red Army troops fighting the insurgency ${ }^{66}$.

This conclusion is also borne out by the evidence we have about the motivations of Ukrainian defectors. It was certainly not unthinkable to go over to the Germans in order to fight for the liberation of Ukraine on the side of the alleged liberators from Bolshevism. But, like in the case of Cossacks or Russians going over to help liberate "Russia" 67 , this was a minority position. Most Ukrainians who decided to go over to the Germans did so either because of more localized reasons (return to the family, threat to the own person) or more universal ones (lack of freedom). In this aspect, they resembled other Soviet defectors. The Ukrainian defectors we met in this paper were thus more "Soviet" than "Ukrainian:" their grievances were those of typical Soviet subjects, not those of essentially Ukrainian personalities.

\section{REFERENCES}

1. Andreyev, C. (1987). Vlasov and the Russian Liberation Movement: Soviet Reality and Émigré Theories. Cambridge, England: Cambridge University Press.

2. Benz, A. (2015). Handlanger Der SS. Die Rolle der Trawniki-Männer im Holocaust. Berlin: Metropol Verlag. [in German].

65 Siegelbaum L., Moch L.P. Broad Is My Native Land: Repertoires and Regimes of Migration in Russia's Twentieth Century. - Ithaca; London, 2014; Idem. Transnationalism in One Country? Seeing and Not Seeing Cross-Border Migration within the Soviet Union // Slavic Review. - 2016. Vol.75. - No.4. - P.970-986.

${ }_{66}$ Statiev A. The Soviet Counterinsurgency in the Western Borderlands. - Cambridge; New York, 2010.

${ }^{67}$ Edele M. Not an Ordinary Man: Ivan Nikitich Kononov and the Problem of Frontline Defection from the Red Army, 1941-1945 // Australian Journal of Politics \& History. - 2016. - Vol.62. No.4. - P.546-560. 
3. Berkhoff, K.C. (2004). Harvest of Despair. Life and Death in Ukraine under Nazi Rule. Cambridge and London: The Belknap Press of Harvard University Press.

4. Berkhoff, K.C. (2012). Motherland in Danger. Soviet Propaganda During World War II. Cambridge, Mass.: Harvard University Press.

5. Black, P. (2011). Foot Soldiers of the Final Solution: The Trawniki Training Camp and Operation Reinhard. Holocaust and Genocide Studies, 1 (25), 1-99.

6. Blackwell, M.J. (2016). Kyiv as a Regime City: The Return of Soviet Power after Nazi Occupation. Rochester: University of Rochester Press.

7. Buchbender, O. (1974). Heil Beil! Flugblattpropaganda im Zweiten Weltkrieg. Dokumentation und Analyse. Stuttgart: Seewald Verlag. [in German].

8. Buchbender, O. (1978). Das tönende Erz. Deutsche Propaganda gegen die Rote Armee im Zweiten Weltkrieg. Stuttgart: Seewald Verlag. [in German].

9. Buchbender, O., Schuh, H. (1983). Die Waffe, die auf die Seele zielt. Psychologische Kriegsführung 1939-1945. Stuttgart: Motorbuch Verlag. [in German].

10. Dumitru, D. (2014). An Analysis of Soviet Postwar Investigation and Trial Documents and Their Relevance for Holocaust Studies. M.David-Fox, P.Holquist, A.M.Martin (Eds.), The Holocaust in the East. Local Perpetrators and Soviet Responses (pp.142-157). Pittsburgh: University of Pittsburgh Press.

11. Edele, M. (1999). Paper Soldiers: The World of the Soldier Hero According to Soviet Wartime Posters. Jahrbücher für Geschichte Osteuropas, 1 (47), 89-108.

12. Edele, M. (2013). "What Are We Fighting For?" Loyalty in the Soviet War Effort, 1941-1945. International Labor and Working-Class History, Fall (84), 248-268.

13. Edele, M. (2016). Not an Ordinary Man: Ivan Nikitich Kononov and the Problem of Frontline Defection from the Red Army, 1941-1945. Australian Journal of Politics \& History, 4 (62), 546-560.

14. Edele, M. (2017). Fighting Russia's History Wars: Vladimir Putin and the Codification of World War II. History and Memory, 2 (29), 90-124.

15. Edele, M. (2017). Stalin's Defectors. How Red Army Soldiers Became Hitler's Collaborators, 1941-1945. Oxford: Oxford University Press.

16. Erlikhman, V.V. (2004). Poteri narodonaseleniia v XX veke. Spravochnik. Moskva: Russkaia panorama. [in Russian].

17. Fitzpatrick, Sh. (1994). Stalin's Peasants. Resistance and Survival in the Russian Village after Collectivization. New York and Oxford: Oxford University Press.

18. Förster, J. (1994). Zum Rußlandbild der Militärs 1941-1945. H.-E.Volkmann (Ed.), Das Rußlandbild Im Dritten Reich (ss.140-163). Cologne, Weimar, Vienna: Böhlau Verlag. [in German].

19. Golczewski, F. (1996). Ukrainische Reaktionen auf die deutsche Besetzung 1939/41. W.Benz et al. (Ed.), Anpassung, Kollaboration, Widerstand. Kollektive Reaktionen auf die Okkupation (ss.199-211). Berlin: Metropol. [in German].

20. Golczewski, F. (1998). Organe der deutschen Besatzungsmacht: die ukrainischen Schutzmannschaften. W.Benz et al. (Ed.), Die Bürokratie der Okkupation. Strukturen der Herrschaft und Verwaltung im besetzten Europa (ss.173-196). Berlin: Metropol. [in German].

21. Hellbeck, J. (1996). Fashioning the Stalinist Soul: The Diary of Stepan Podlubnyi (1931-1939). Jahrbücher für Geschichte Osteuropas, 3 (44), 344-375.

22. Hellbeck, J. (2015). Stalingrad: The City That Defeated the Third Reich. New York: Public Affairs.

23. Hilger, A., Overmans, R., Polian, P. (2012). Rotarmisten in deutscher Hand. Dokumente zu Gefangenschaft, Repatriierung und Rehabilitierung sowjetischer Soldaten des Zweiten Weltkrieges. Paderborn: Ferdinand Schöningh. [in German].

24. Kirschenbaum, L.A. (2000). "Our City, Our Hearths, Our Families": Local Loyalties and Private Life in Soviet World War II Propaganda. Slavic Review, 4 (59), 825-847.

25. Krylova, A. (2010). Soviet Women in Combat. A History of Violence on the Eastern Front. Cambridge and New York: Cambridge University Press. 
26. Kuby, E. (2010). Mein Krieg: Aufzeichnungen aus 2129 Tagen, $3^{\text {rd }}$ ed. Berlin: Aufbau. [in German].

27. Kudryashov, S. (2005). Ordinary Collaborators: The Case of the Travniki Guards. L.Erickson, M.Erickson (Ed.), Russia. War, Peace and Diplomacy. Essays in Honour of John Erickson (pp.226-239). London: Weidenfeld \& Nicholson.

28. Kumanev, G.A. (2001). Evakuatsiia naseleniia iz ugrozhaemykh raionov SSSR v 1941-1942 gg. Iu.A.Poliakov (Ed.), Naselenie Rossii v XX veke. Istoricheskie ocherki. Vol.2: 1940-1959 (pp.60-81). Moskva: ROSSPEN. [in Russian].

29. Liber, G.O. (2016). Total Wars and the Making of Modern Ukraine, 1914-1954. Toronto: University of Toronto Press.

30. Lytvyn, V. (Ed.). (2007). Ukraina: Politychna istoriia. XX-pochatok XXI stolittia. Kyiv: Parlamentske vydavnytstvo. [in Ukrainian].

31. Lower, W. (2005). Nazi Empire-Building and the Holocaust in Ukraine. Chapel Hill: The University of North Carolina Press.

32. Markwick, R.D., Cardona, E. (2012). Soviet Women on the Frontline in the Second World War. Houndmills: Palgrave Macmillan.

33. Nikolskyi, V.M. (2003). Represyuna diialnist orhaniv derzhavnoi bezpeky SRSR v Ukraini (kinets 1920-kh-1950-ti rr.): Istoryko-statystychne doslidzhennia. Donetsk: DNU. [in Ukrainian].

34. Osterloh, J. (1996). Sowjetische Kriegsgefangene 1941-1945 im Spiegel nationaler und internatioanler Untersuchungen. Forschunsüberblick und Bibliographie, 2nd. rev. ed. Dresden: Hannah-Arendt-Institute für Totalitarismusforschung. [in German].

35. Penter, T. (2005). Collaboration on Trial: New Source Material on Soviet Postwar Trials against Collaborators. Slavic Review, 4 (64), 782-790.

36. Plokhii, S. (2014). Kak Stalin poterial golovu. Vtoraia mirovaia voina i voiny pamiati v sovremennoi Ukraine. O.Budnitskii, L.Novikova (Ed.), SSSR vo Vtoroi mirovoi voine. Okkupatsiia, Kholokost, stalinizm (pp.392-410). Moskva: ROSSPEN. [in Russian].

37. Plokhy, S. (2011). The Call of Blood. Government Propaganda and Public Response to the Soviet Entry into World War II. Cahiers du Monde russe, 2-3 (52), 293-319.

38. Pohl, D. (2011). Die Herrschaft der Wehrmacht. Deutsche Militärbesatzung und einheimische Bevölkerung in der Sowjetunion 1941-1944. Frankfurt a. M.: S.Fischer. [in German]. 39. Potichnyj, P.J. (1986). Ukrainians in World War II Military Formations: An Overview. Y.Boshyk (Ed.), Ukraine during World War II. History and its Aftermath. A Symposium (pp.61-66). Edmonton: Canadian Institute of Ukrainian Studies.

40. Prusin, A. (2007). Ukrainskaia politsiia i Kholokost v generalnom okruge Kiev, 1941-1943: deistviia i motivatsii. Holokost $i$ suchasnist: studii v Ukraini $i$ sviti, 1, 31-59. [in Russian].

41. Reese, R. (2011). Why Stalin's Soldiers Fought. The Red Army's Military Effectiveness in World War II. Lawrence: University Press of Kansas.

42. Rogachevskaia, L.S., Kabuzan, M.V. (2001). Naselenie i territoriia SSSR i RSFSR nakanune Velikoi Otechestvennoi voiny. Iu.A.Poliakov (Ed.), Naselenie Rossii v XX veke. Istoricheskie ocherki. Vol.2: 1940-1959 (pp.6-18). Moskva: ROSSPEN. [in Russian].

43. Rossolinski-Liebe, G. (2014) Stepan Bandera. The Life and Afterlife of a Ukrainian Nationalist. Fascism, Genocide, and Cult. Stuttgart: Ibidem.

44. Rudakova, D. (2016). Soviet Women Collaborators in Occupied Ukraine 1941-1945. Australian Journal of Politics \& History, 4 (62), 529-545.

45. Seniavskaia, E.S. (1995). 1941-1945. Frontovoe pokolenie. Istoriko-psikhologicheskoe issledovanie. Moskva: RAN, Institut rossiiskoi istorii. [in Russian].

46. Shneer A. (2005). Plen. Sovetskie voennoplennye v Germanii, 1941-1945. Moskva; Jerusalem: Mosty kultury, Gesharim. [in Russian].

47. Siegelbaum, L., Moch, L.P. (2014). Broad Is My Native Land. Repertoires and Regimes of Migration in Russia's Twentieth Century. Ithaca; London: Cornell University Press.

48. Siegelbaum, L., Moch, L.P. (2016). Transnationalism in One Country? Seeing and Not Seeing Cross-Border Migration within the Soviet Union. Slavic Review, 4 (75), 970-986. 49. Skorobohatov, A.V. (2004). Kharkiv u chasy nimetskoi okupatsii (1941-1943). Kharkiv: Prapor. [in Ukrainian]. 
50. Snyder, T. (2010). Bloodlands. Europe between Hitler and Stalin. London: Bodley Head. 51. Statiev, A. (2010). The Soviet Counterinsurgency in the Western Borderlands. Cambridge and New York: Cambridge University Press.

52. Streit, C. (1997). Keine Kameraden. Die Wehrmacht und die sowjetischen Kriegsgefangenen 1941-1945, new ed. Bonn: Dietz. [in German].

53. Tessin, G. (1974). Verbände und Truppen der deutschen Wehrmacht und Waffen-SS im Zweiten Weltkrieg 1939-1945. Vol.9. Osnabrück: Biblio Verlag, 1974. [in German].

54. Voisin, V. (2015). L'URSS contre ses traîtres: L'Épuration soviétique (1941-1955). Paris: Publications de la Sorbonne. [in French].

55. Von Hagen, M. (2007). War in a European Borderland. Occupations and Occupation Plans in Galicia and Ukraine, 1914-1918. Seattle; London: University of Washington Press.

МАРк Еделе

доктор філософії, професор історії, заступник керівника, Школа історико-фрілософських студій (SHAPS), Мельбурнський університет (Мельбурн, Австралія), mark.edele@unimelb.edu.au ORCID: https://orcid.org/0000-0002-1783-7662

\title{
ЧОМУ ЧЕРВОНОАРМІЙЦІ-УКРАЇНЦІ ПЕРЕЙШЛИ ДО НІМЦІВ? СПРАВА ПЕРЕБІЖЧИКІВ ДО 296-ї ПІХОТНОї ДИВІЗІї ВЕРМАХТУ, 1942-1943 рp.
}

\begin{abstract}
Анотація. Метою иього дослідження став аналіз причин перебіжництва серед червоноармійиів-украӥниів під час Другої світової війни. Методологія становить собою поєднання кількісного таякісного методів. Предметол аналізу виступають написані оббіцерол контррозвідки 296-ї піхотної дивізї̈ вермахту протоколи допитів перебіжчиків-червоноарлійців - як з огляду на характер причин, котрі спонукали їх перетнути лінію фбронту, так $і$ на частоту мотивів різних категорій. Ці дані порівнюються з показниками більшої групи радянських перебіжчиків різних національностей. Наукова новизна полягае в поєднанні культурної історії з квантитативнил підходом $i$ застосуваннял методологї, розробленої для вивчення проблеми перебіжчиків-червоноармійців у цілому та підгрупи україниів зокрела. Джерельна база статті складається з украӥнських та російських архівних матеріалів, які доповнюють дані нілецького військового архіву. Висновки. У иілому мотивація украӥнців не надто відрізнялася від тієї, яку мали радянські перебіжчиків інших національностей. Хоча украӥниі часто були більш політизованили, але назагал соціальні й політичні нарікання, що їх вони висловлювали, поділяли багато радянських гроладян. Чилало українських перебіжчиків, які були достатньо політизованими для бажання боротися проти "совєтів", за звільнення "Батьківщини", уявляли під останньою радше багатонаціональний СРСР, аніж суто украӥнську національну територію. Мотиви політизованих українців були власне політичними (відсутність свободи, репресіі) або соціальними (колгоспи, жахливі умови життя), а не національнили (свобода для Украӥни). Украӥнські націоналісти становили меншість серед перебіжчиків $i$ найчастіше походили з колишніх польських територій, анексованих на початку Другої світової війни в Європі.
\end{abstract}

Keywords: Друга світова війна, перебіжчики, украӥнські перебіжчики, 296-та піхотна дивізія вермахту. 